\title{
The Gall Maker Neopelma baccharidis Burck. (Homoptera:Psyllidae) on Baccharis dracunculifolia DC. (Asteraceae): Individual, Local, and Regional Patterns
}

\author{
Rosane G. Collevatti ${ }^{1}$ and Carlos F. Sperber ${ }^{2}$ \\ ${ }^{1}$ Departamento de Ecologia, Universidade de Brasília, 70910-900 Brasília, DF. \\ ${ }^{2}$ Setor de Ecologia, Departamento de Biologia Geral, Universidade Federal de Viçosa, \\ 36571-000 Viçosa, MG.
}

\begin{abstract}
An. Soc. Entomol. Brasil 26(1): 45-53 (1997)
O Galhador Neopelma baccharidis Burck. (Homoptera: Psyllidae) em Baccharis dracunculifolia DC. (Asteraceae): Padrões Individuais, Locais e Regionais
\end{abstract}

\begin{abstract}
RESUMO - Baccharis dracunculifolia, planta hospedeira do galhador Neopelma baccharidis Burck., apresenta distribuição local em manchas definidas. Nesse trabalho, analisou-se o efeito de características individuais da hospedeira (altura da planta, diâmetro e volume da copa), locais (mancha) e regionais (localidade) no número de galhas, em Viçosa (três manchas) e Parque Estadual do Rio Doce,

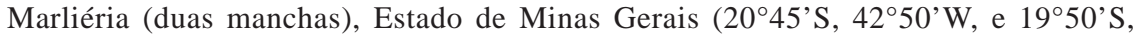
$42^{\circ} 30^{\prime} \mathrm{W}$, respectivamente). O número de galhas/planta foi positivamente correlacionado com o tamanho da planta e esta relação foi a mesma entre manchas e localidades. Foram encontradas diferenças entre manchas na proporção de plantas com galha versus sem galha, mas não entre localidades. A proporção de plantas com galha na mancha foi relacionada ao tamanho das plantas, e não à área da mancha. Plantas sem galhas apresentaram distribuições de freqüência de suas dimensões diferentes de plantas com galhas, com maior número de plantas pequenas, o que indicou haver um tamanho mínimo dos indivíduos de $B$. dracunculifolia para que sejam atacados por $N$. baccharidis. Concluiu-se que fatores locais prevaleceram sobre fatores regionais na determinação do número de galhas de $N$. baccharidis sobre $B$. dracunculifolia, na medida em que alteraram o tamanho das plantas, e com isso sua conveniência para o galhador, sem alterar a relação da carga de galhas com as dimensões individuais das plantas.
\end{abstract}

PALAVRAS-CHAVE: Insecta, galhas, Parque Estadual do Rio Doce, herbivoria, arquitetura da planta.

ABSTRACT - Baccharis dracunculifolia, the host plant of the gall maker Neopelma baccharidis Burck., is locally distributed in delimited patches. The effects of the host plant individual (plant height, crown diameter, and crown volume), local (host plant patch), and regional (locality) characteristics on the number of galls were analyzed, in Viçosa (three patches) and in Rio Doce State Park, Marliéria (two patches), Minas Gerais State $\left(20^{\circ} 45^{\prime} \mathrm{S}, 42^{\circ} 50^{\prime} \mathrm{W}\right.$; and $19^{\circ} 50^{\prime} \mathrm{S}, 42^{\circ} 30^{\prime} \mathrm{W}$, respectively). The number of galls/individual plant increased homogenousliy with plant dimensions on local and regional scale. Gall load was also homogenous, 
but the proportion of galled plants differed on a local scale. The differences were related to local plant size differences, and not to host plant patch size. Plants without galls presented different frequency distributions of plant dimensions than galled plants, with greater number of little plants, which indicated a minimum plant size to be gall maker prone. Local factors prevailed over regional factors in determining the number of $N$. baccharidis galls on 5. dracunculifolia, affecting the size of individual plants and suitability to the gall maker, without modifying the relationship between gall load and plant dimensions.

KEY WORDS: Insecta, galls. Parque Estadual do Rio Doce, herbivory, plant architecture.

Herbivore occurrence is generally affected by the spatial distribution of its host plants (Strong et al. 1984). Large patches of host plants may present higher densities of specialized herbivores, because of higher probability of locating and remaining on these resources (Root 1973). Higher immigration/ emigration ratios (MacArthur \& Wilson 1967, Raupp \& Denno 1979, Kareiva 1985), or higher local population carrying capacity can account for these trends. If there is aggregated and unpredictable mortality, the herbivore may "spread the risk" among host plants (Root \& Kareiva 1984), leading to the opposite pattern (Courtney \& Courtney 1982).

The size of the individual plant may work in the same way as patch size, although not necessarily with the same trends. Larger plants may be more often found by herbivores (Feeny 1976, Lawton 1983), or may support greater populations of its consumers, mitigating the local extinction rate. Lara \& Fernandes (1994) verified that the number of Neopelma baccharidis Burck. (Homoptera:

Psyilidae) galls on Baccharis dracunculifblia (Asteraceae) increased with plant height and that galled branches were smaller and had less leaves than non-galled branches.

Recently, the ecological literature focused on development of metapopulation models, where the dynamics of local and regional populational processes interact (Gilpin \& Hanski 1991). In these models the local population dynamics can be simplified to local presence or absence of the organism, regulated by colonization and local extinction (Verboom \& Lankester 1991). To evaluate such models it is important to establish the importance of local and regional processes to population dynamics.

$B$. dracunculi folia is a dioecious perennial shrub, $4 \mathrm{~m}$ height, that occurs in southeastern and central Brazil, and possibly in other contiguous regions of South America, where it invades pastures (Lorenzi 1982), resprouting when cut down. Individual plants are locally distributed in well delimited patches.

The jumping plant lice $N$. baccharidis induces the most common gall of B. dracunculifolia (Lara \& Fernandes 1994). The hole leaf is swollen, with its borders joined but not melted, forming an inner chamber, covered with the gall maker's produced silk, and inhabited by one to $10 \mathrm{~N}$. baccharidis nymphs. Galls are, also, occupied by other arthropods, such as Diptera, Hemiptera, Homoptera (Aphididae), Neuroptera (Chrysopidae), Thysanoptera and Acarina immatures (RGC personal observation). These locatari (Mani 1964) may utilize the chamber for protection, consuming the gall maker's silk and plant products, but can also predate on the gall maker, and/or gall tissues. With the gall maker's maturity the gall opens and the adult gall maker exits the gall. Thereafter, the gall dries up and falls from the stem.

This work tested if there is spatial heterogeneity of gall maker attack in two spatial 
scales: local, between host plant patches and regional, between different localities (Viçosa and Rio Doce State Park). The hypothesis of the number of galls of $N$. baccharidis on $B$. dracunculifolia is positively related with host plant patch size was tested, as well.

\section{Material and Methods}

Five host $B$. dracunculifolia patches, ranging from 18 to $12,000 \mathrm{~m}^{2}$, were sampled. Three patches (I, II and III) were located at Viçosa, MG $\left(20^{\circ} 45\right.$ 'S, $\left.42^{\circ} 50^{\prime} \mathrm{W}\right)$, within one to $10 \mathrm{~km}$ distance between each other, and two (IV and V) at Rio Doce State Park, Municipality of Marliéria, MG (19 $\left.50^{\circ} \mathrm{S}, 42^{\circ} 30^{\prime} \mathrm{W}\right), 200$ $\mathrm{km}$ away from Viçosa, and $2 \mathrm{~km}$ apart of each other. Individual plants on the same place spaced $10 \mathrm{~m}$ were considered of the same patch. Patch size was estimated by plotting the spatial position of each individual plant on millimeter paper and measuring the area.

Plant height and crown diameter (plant dimensions) of all individual plants in each patch were measured, except on the largest patch, where a sample of $232 \mathrm{~m}^{2}$ was taken. A total of 772 individual plants were sampled, 232 of them in the largest patch.

To evaluate the influence of plant size on the number of galls/individual host plant, and the spatial heterogeneity of this influence, an hierarchical analysis of covariance (HANCovA) was made (Sokal \& Rolf 1981). The dependent variable was the number of galls/ individual plant; the covariates were plant height, crown diameter, and the interaction of these variables, which indicated a "crown volume" effect. The two categorical variables were locality and host plant patch, nested within locality.

To obtain normally distributed residuals, plants without galls were excluded from the analysis, and the natural logarithm of gall load was taken. This procedure also assured linearity. The residuals were plotted within each lowest category (host plant patch), to test the assumptions of the analysis (Day \& Quinn 9). Outliers were excluded when Student's corrected residuals exceeded three, in abso- lute value. Exceedingly influential points were excluded when a high leverage value was associated with high Cook values (Chatterjee \& Price 1991). High values were considered those which exceeded the values of the remaining points. Autocorrelation and collinearity were ignored (Brook \& Amold 1985), although discussed later.

Heterogeneity between categories could be manifested in two different ways: the slopes of the regressions could differ between host plant patches or localities, or the number of galls/individual plant could differ from the expected for the observed plant sizes (differences in gall load), despite homogenous slopes. Host plant patches II and III were excluded from these analyses because they presented low number of plants with galls (zero and four, respectively, the latter with one outlier). Homogeneity of slopes was tested separately for host plant patches and locality. Between host plant patches, the summing a of all first- and second-order interactions of the categorical variable with the covariates was tested, within a simplified analysis of covariance (ANCOVA) model, excluding locality and second order interaction of the covariates. Between localities the model was the fully saturated HANCOVA. The direct effect of the categorical variables were tested when there was homogeneity of slopes (Huitema 1980).

B. dracunculifolia individualis with galls could present different allometric characteristics then plants without galls. To test this hypothesis, the height and crown diameter of plants with versus without galls were compared with a test for central tendency (Student's t test or Mann-Whitney U test, when transformations had not provided homocedasticity) and another test for the shape of the distribution of frequencies (KolmogorovSmimov).

Spatial heterogeneity of gall maker attack was also tested for the proportion of plants with galls, separately between host plant patches and between localities, with Pearson's Chi-square. 
The relation of gall maker attack and host plant patch area was evaluated comparing the proportion of galled plants in each host plant patch with the area of the patch. If there was a correlation of these, it was expected that host plant patches of greater area presented greater proportion of galled plants.

\section{Results}

The number of galls per individual $B$. dracunculifolia was positively correlated with plant height (Fig. 1), crown diameter (Fig. 2), and crown volume (Table 1). The slopes were homogeneous, hence, correlations were not affected by local nor regional spatial scale (interactions of host plant patches with plantdimensions, $\mathrm{F}=0.88,6$ and 84 d.f., $\mathrm{P}=0,512$; interactions of locality with plant dimensions, $\mathrm{F}=1.40,3$ and 87 d.f., $\mathrm{P}=0.249$ ).

Plants without galls were lower (plant height square root transformed, $\mathrm{t}=20,26, \mathrm{P}<$ 0.001 ) and presented narrower crowns (MannWhitney's U test, Chi-squared $=201.89, \mathrm{P}<$ $0.001)$ then galled plants. Furthermore, the frequency distribution of plant dimensions was different between plants with and without galls (Fig. 3). Plants with galls presented more symmetrical frequency distributions, whereas plants without galls presented highly skewed frequency distributions, with the mode on little plants.

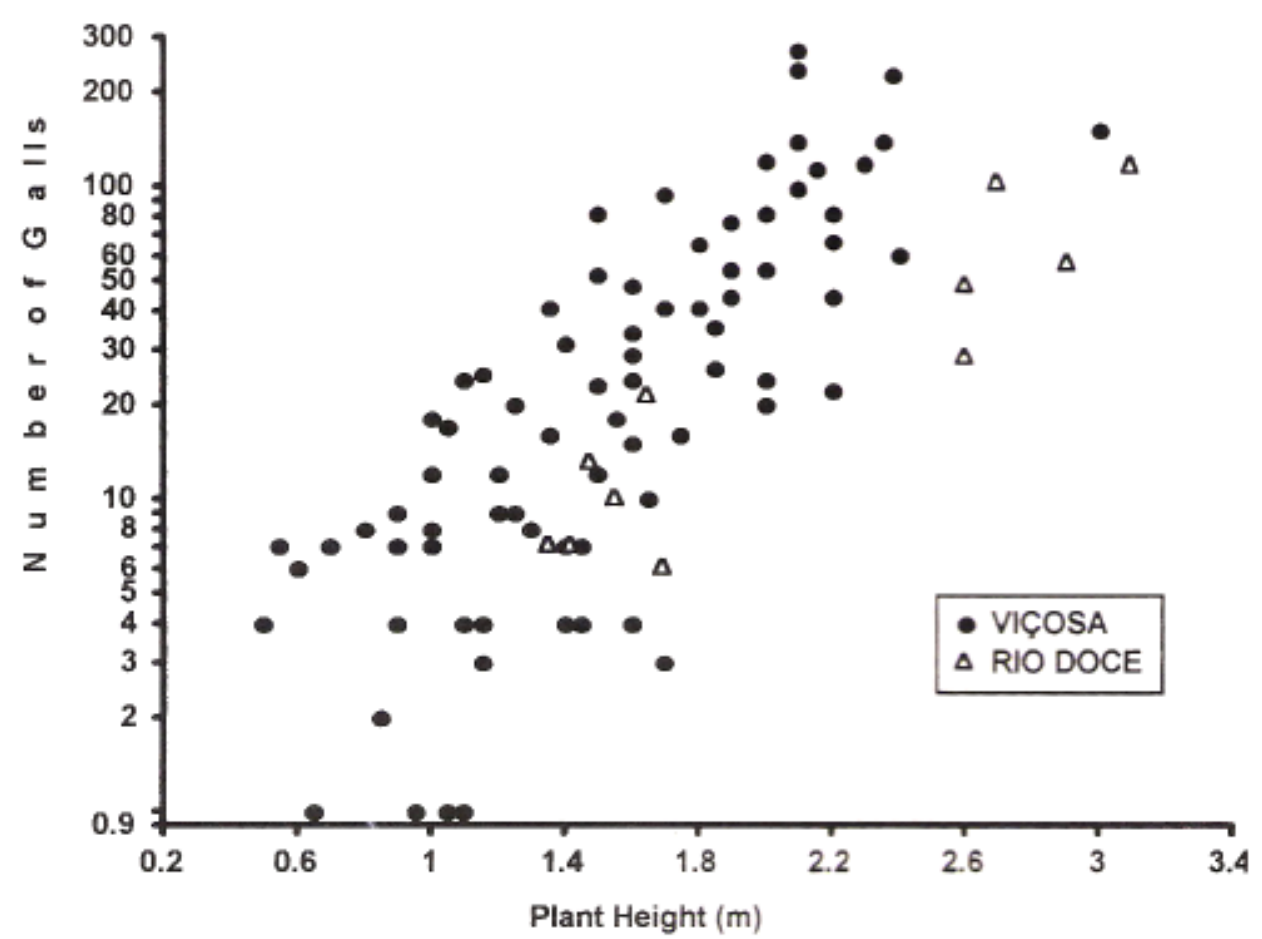

Figure 1. Natural logarithm of the number of galls per individual Baccharis dracunculifolia plotted against plant height (m). RDOCE: Rio Doce State Park, VIÇOSA: Viçosa 


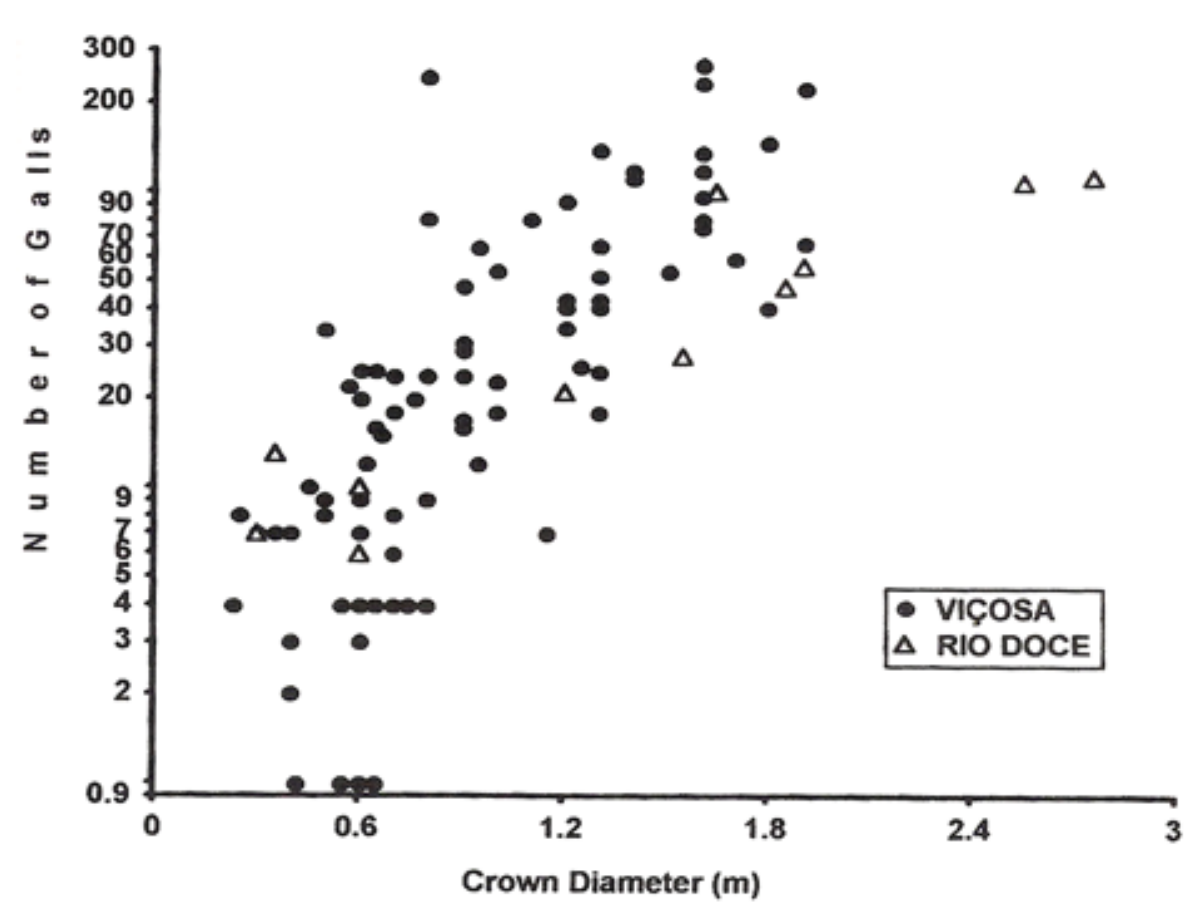

Figure 2. Natural logarithm of the number of galls per individual Baccharis dracunculifolia plotted against crown diameter (m). RDOCE: Rio Doce State Park, VIÇOSA: Viçosa

There were no differences in gall load between host plant patches nor localities (Table 1). On the other hand, the proportion of plants with versus without galls was heterogeneous on a local scale (Table 2), whereas not on a regional scale (Chi-squared $=0.38, \mathrm{P}=0.54$ ).

The proportion of galled plants per host plant patch was not correlated to patch size. There was a positive correlation of the proportion of galled plants per patch and the mean size of the plants in the patch (Table 2).

\section{Discussion}

The positive correlation of number of galls with plant size was probably a result of sampling effect, promoted by greater amount of leaf-bud, the resource for the gall maker, in larger plants, leading to an "area per se" effect (Strong et al. 1984). Nevertheless, encounter frequency and resource concentration effect would cause the same pattern (Root 1973, Southwood \& Kennedy 1983, Lewinsohn 1991). Although the plant dimension terms used - height, crown diameter, and the interaction of these - are colinear, the results presented show that each of them plays an independent role as covariate.

The differences in the frequency distributions of plant dimensions between plants with versus without galls suggest that there is a minimum plant size to be "gall maker prone". Plant size or age and phenological stage may influence ovipositional behavior or insect performance (variation in growth rate, survivorship) due to differences in resource availability (buds), chemical and physical defences, and "enemy free space" (Atsatt 1981, Price 1989, Homer \& Abrahamson 1992, Mopper \& Simberloff 1995).

The homogeneity of gall load in local and regional scale contrasted with the heteroge- 


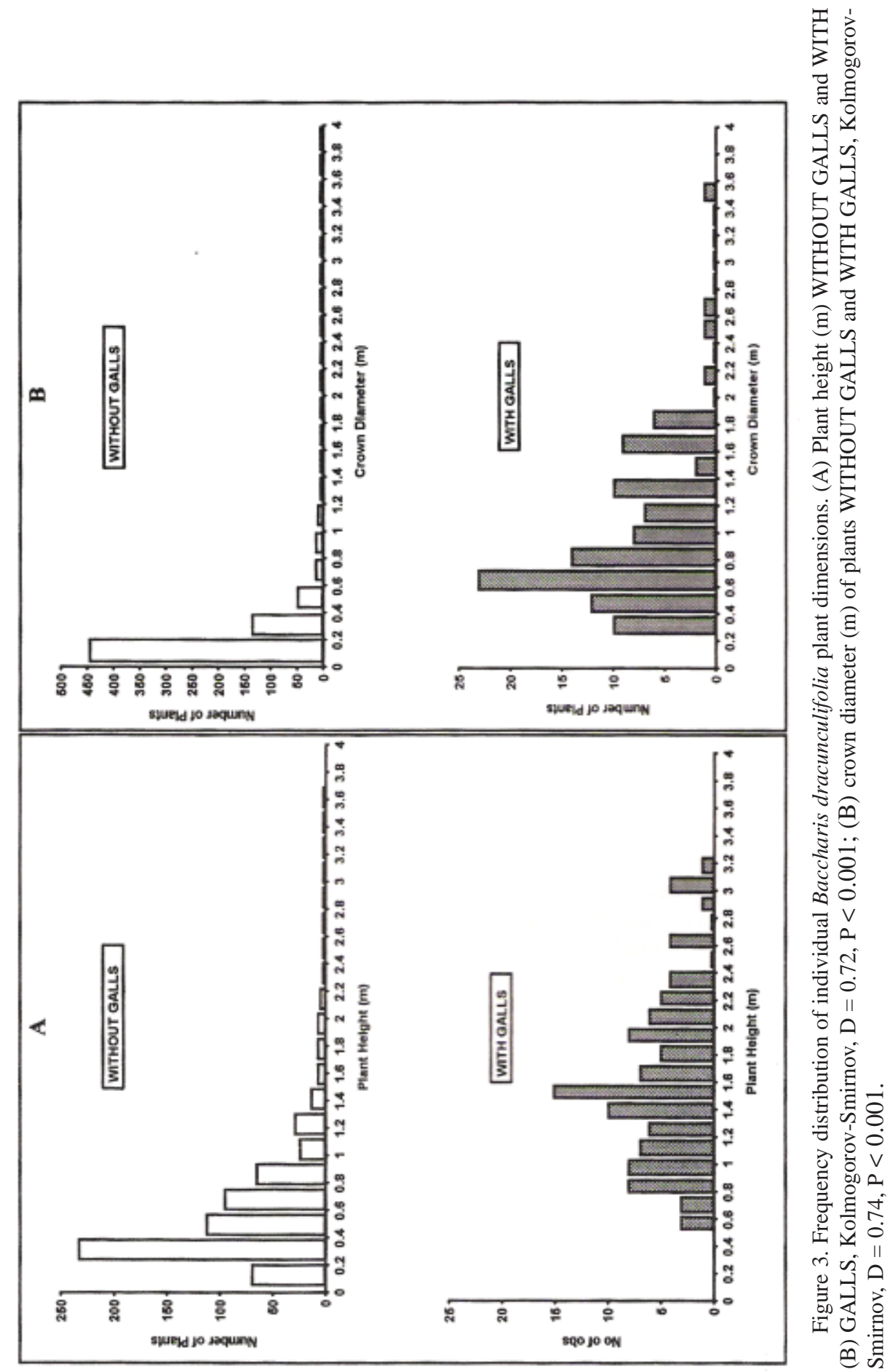


Table 1. Hierarchical analysis of covariance of the number of galls per individual Baccharis dracunculifolia (transformed with natural logarithm), with plant height, crown diameter, and the interaction of these as covariates, locality and host plant patch, the latter nested within locality, as categorical variables.

\begin{tabular}{lcccc}
\hline Source & Sum-of-squares & Degrees of freedom & F & P \\
\hline Locality & 2.05 & 1 & 3.56 & 0.063 \\
$\begin{array}{l}\text { Host plant patch } \\
\text { (locality) }\end{array}$ & 0.29 & 1 & 0.50 & 0.482 \\
Plant height & 20.30 & 1 & 35.2 & $<0.001$ \\
Crown diameter & 10.30 & 1 & 17.86 & $<0.001$ \\
Plant height* & 4.40 & 1 & 7.63 & 0.007 \\
Crown diameter & 51.89 & 90 & & \\
Error & & & & \\
\hline
\end{tabular}

Table 2. Characteristics of the five Baccharis dracunculifolia patches studied. Plant height and crown diameter: means (standard deviations). The statistics in the 7 th column refer to comparisons in the row. $\mathrm{N}=$ sample size.

\begin{tabular}{|c|c|c|c|c|c|c|}
\hline & Patch I & Patch II & Patch III & Patch IV & Patch V & Statistics \\
\hline Locality & Viçosa & Viçosa & Viçosa & Rio Doce & Rio Doce & - \\
\hline Patch area $(\mathrm{m} 2)$ & 12000 & 25 & 600 & 18 & 55 & - \\
\hline Plant height (m) & $0.94(0.69)$ & $0.63(0.31)$ & $0.50(0.32)$ & $1.67(0.77)$ & $0.99(0.83)$ & $\begin{array}{l}\text { Kruskal-Wallis } \\
-86.36 \\
P<0.001\end{array}$ \\
\hline Crown diameter $(\mathrm{m})$ & $0.57(0.55)$ & $0.25(0.32)$ & $0.20(0.21)$ & $0.64(0.72)$ & $0.45(0.66)$ & $\begin{array}{l}\text { Kruskal-Wallis } \\
=72.37 \\
\mathrm{P}<0.001\end{array}$ \\
\hline $\begin{array}{l}\text { Plants with } \\
\text { galls (\%) }\end{array}$ & 37 & 0 & 1.5 & 38 & 12 & $\begin{array}{l}\text { Chi-squared } \\
=176.89 \\
P<0.001\end{array}$ \\
\hline $\mathrm{N}$ & 232 & 180 & 264 & 13 & 83 & $\begin{array}{l}\text { Total number } \\
=772\end{array}$ \\
\hline
\end{tabular}

neity in the proportions of galled plants/patch. Regional (altitudinal) homogeneity of gall load had been observed in several species of Baccharis (Carneiro \& Fernandes 1996). Lo- cal homogeneity of gall load reveals the absence of local genotipic differences in gall maker proneness between host plant: only size related characteristics of the plant were involved. 
The differences in the proportion of galled plants per patch resulted from local characteristIcs of the plant patches, which affected individual plant size. These phenotype differences between patches could be determined by local habitat quality or local history - in better quality conditions (e.g., soil, moisture), plants would grow larger, and in older or less disturbed plant patches, there could be older, larger plants (White \& Pickett 1985).This prevalence of local, rather than regional factors counters the recent ecological theory "fashion" of emphasis in regional scale processes (Gilpin \& Hanski 1991, Ricklefs \& Schiuter 1993).

The gall maker/V. baccharidis is, therefore, only affected by host plant size, which varies on a local scale, and presents no other spatial heterogeneity in the number of galls/individual plant. Gall load increases with plant size, with little plants "escaping" gall maker attack.

\section{Acknowledgements}

To the Instituto Estadual de Florestas (IEF) and to the PERD administration, for the accommodation and research facilities, to Dr. Daniel Burckhardt, for the identifications, to Katherine W. Linares and Maria C. Viana, for helping in the field work, to Júlio N. C. Louzada, for the good ideas, to Geraldo W. Fernandes, for the incentive and initial identifications, to Thomas M. Lewinsohn, for the initial idea of the research subject, to Frederico S. Lopes, and Og DeSouza, for reading different versions of the manuscript and giving valuable suggestions.

\section{References Cited}

Atsatt, RR. 1981. Lycaenid butterflies and ants: selection for enemy-free space. Am. Nat. 118:638-654.

Brook, R.J. \& G.C. Arnold 1985. Applied regression analysis and experimental design. NewYork, Marcel Dekker, 237 p.
Carneiro, M.A.A. \& G.W. Fernandes 1996. Sexo, drogas e herbivoria. Ciência Hoje 20:34-39.

Chatterjee, S. \& B. Price 1991. Regression analysis by example. 2nd., NewYork, John Wiley \& Sons, 278 p.

Courtney, S.P. \& S. Courtney. 1982. The "edge-effect" in butterfly oviposition: causality in Anthocharis cardamines and related species. Ecol. Entomol. 7:131-137.

Day, R.W. \& G.P. Quinn 1989. Comparisons of treatments after an analysis of variance in ecology. Ecol. Monog. 59:433-463.

Feeny, P.P. 1976. Plant apparency and chemical defence, p. 1-40. In J. Wallace \& R. L. Mansell (eds.). Biochemical interactions between plants and insects. New York, Plenum Press, 439 p.

Gilpin, M. \& I. Hanski. 1991. Metapopulation dynamics: empirical and theoretical investigations. London, Academic Press / Harcourt Brace Jovanovich, 336 p.

Horner, J.D. \& W.G. Abrahamson. 1992. Influence of plant genotype and environment on oviposition preference and offspring survival in a gallmaking herbivore. Oecologia 90:323-332.

Huiteina, B.E. 1980. The analysis of covariance and its alternatives. Oxford, WileyInterscience, 330p.

Kareiva, P. 1985. Finding and losing host plants by Phyllotlotreta: patch size and surrounding habitat. Ecology 66: 1809-1816.

Lara,A.C.F. \& G.W. Fernandes. 1994. Distribuição de galhas de Neopelma baccharidis (Homoptera: Psyilidae) em Baccharis dracunculifolia (Asteraceae). Rev. Brasil. Biol.54:661-668. 
Lawton, J.H. 1983. Plant architecture and the diversity of phytophagous insects. Annu. Rev. Entomol. 28: 23-39.

Lewinsohn.T.M. 1991. Insects in flower heads of Asteraceae in southeast Brazil: a case study on tropical species richness. p.525559. In P.W, Price.T.M. Lewinsohn, G.W. Fernandes \& W.W. Benson (eds.). Plantanimal interactions: evolutionary ecology in tropical and temperate regions. New York, John Wiley \& Sons, Inc., 639 p.

Lorenzi, H. 1982. Plantas daninhas do Brasil: terrestres, aquáticas, parasitas, tóxicas e medicinais. Nova Odessa, SP, Edição do Autor, $425 \mathrm{p}$.

MacArthur,R.H.\& E.O.Wilson. 1967. The theory of island biogeography. Princeton, Princeton University Press, 203 p.

Mani, M.S. 1964. Ecology of plant galls. The Hague, Dr. W. Junk, 434 p.

Mopper, S. \& D. Simberloff 1995. Differential herbivory in an oak population: the role of plant phenology and insect performance. Ecology 76:1233-1241.

Price, P.W. 1989. Clonal development of coyote willow, Salix exigua (Salicaceae), and attack by the shoot-galling sawfly, Euura exiguae (Hymenoptera: Tenthredinidae). Environ. Entomol. 18:62-68.

Raupp, MJ. \& R.F. Denno. 1979. The influence of patch size on a guild of sap-feeding insects that inhabit the salt marsh grass Spartinapatens. Environ. Entomol. 8:412-417.

Ricklefs, R.E. \& D. Schluter (eds.) 1993. Species diversity in ecological communi- ties: historical and geographical perspectives. Chicago, The University of Chicago Press, 416 p.

Root, R.B. 1973. Organisation of a plant-arthropod association in a simple and diverse habitats: the fauna of collards (Brassica oleracea). Ecol. Monog. 43: 95-124.

Root, R.B. \& P.M. Kareiva. 1984. The search for resources by cabbage butterflies (Pieris rapae): ecological consequences and adaptive significance of Markovian movements in a patchy environment. Ecology 65:147-165.

Sokal, R.R. \& RJ. Rohlf. 1981. Biometry. 2nd, San Francisco, W. H. Freeman, 859 p.

Southwood,T.R.E. \& Kennedy, C.E.J. 1983. Trees as islands. Oikos 41:359-371.

Strong, D.R., J.H. Lawton \& T.R.E. Southwood. 1984. Insects on plants: community patterns and mechanisms. Oxford, Blackwell Scient.Publ.,313p.

Verboom, J. \& K. Lankester 1991. Linking local and regional dynamics in stochastic metapopulation models. Biol. J. Linn. Soc. 42:39-55.

White, P.S. \& Pickett, S.T.A. 1985. Natural disturbance and patch dynamics: an introduction. p. 3-13. In S.T.A. Pickett \& P.S. White (eds.). The ecology of natural disturbance and patch dynamics. San Diego, Academic Press, 472 p.

Received in 16/VII/96. Accepted 15/1/97. 